\title{
Potensi Inovasi Untuk Meningkatkan KesejahteraAn Masyarakat Desa
}

jurnal.kemendagri.go.id/index.php/ $\mathrm{mp}$

\section{e-ISSN: 2549-5283}

p-ISSN: 2549-5151

Matra Pembaruan 4 (2) (2020): 93107

DOI:-

10.21787/mp.4.2.2020.93-107

Keywords: Village Funds, Cash For Work, $A D D$

Kata Kunci: inovasi, perdesaan, sumber daya, kemiskinan

\section{${ }^{*}$ Korespondensi \\ Phone : +62 85227001825 \\ Email :01arifsofianto@gmail. com}

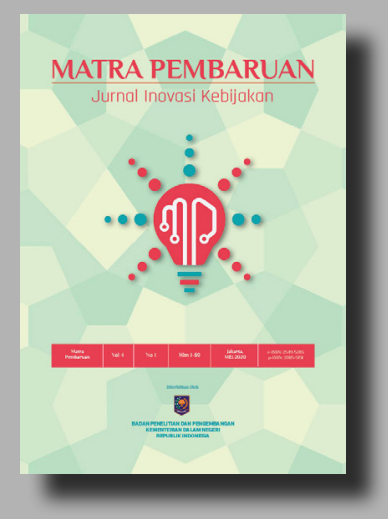

BADAN PENELITIAN DAN PENGEMBANGAN (BPP) KEMENTERIAN DALAM NEGERI

Jl. Kramat Raya No 132, Jakarta Pusat, 10450

\section{(C)2020 Arif Sofianto}

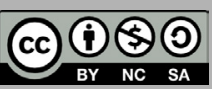

Karya ini dilisensikan di bawah Lisensi Internasional Creative Commons Atribusi Nonkomersial Sharealike 4.0.

\author{
Arif Sofianto* \\ Bappeda Provinsi Jawa Tengah \\ Jl. Pemuda 127 - 133 Semarang
}

Dikirim: 15 Juni 2020; Direvisi: 19 Oktober 2020;

Disetujui: 11 November 2020

\section{Asbtract}

The village has many dilemmas, where many resources are exploited, but low welfare. Innovation is one of the important keys for village communities to solve these problems. This research was aimed to 1) Identifying the potential of village resources through innovation; 2) Identifying protection campaigns; 3) Analyze the key factors for the development of innovation in Central Java. This is a qualitative descriptive study, conducted in 22 villages which has a high poverty rate, but has a large potential resources. The research involved informants from the village head, village administration apparatus, and community group representatives. Data collection using interviews, questionnaires, and FGD. Data analysis using Miles and Huberman techniques. The conclusions of this study are: 1) Natural, human, social and economic resources that are managed in new ways through tourism activities, creative industries, and postharvest product processing. 2) Innovation constrained of limited ideas, lack of pioneering and entrepreneurial spirit, limited knowledge and technology, low community participation, and weak role of village institutions. 3) Key factors that drive the development of innovation are the existence of pioneering figures who are willing to take risks and have different ideas and are supported by the village government by involving relevant stakeholders.

\section{Inti Sari}

Desa menghadapi dilema, dimana banyak sumber daya, namun kesejahteraan rendah, meskipun eksploitasi sumber daya alam tinggi. Inovasi merupakan salah satu kunci penting bagi masyarakat desa untuk menghadapi masalah tersebut. Tujuan penelitian untuk: 1) Mengidentifikasi potensi sumber daya desa melalui inovasi; 2) Mengidentifikasi kendalakendala inovasi perdesaan; 3) Menganalisis faktor-faktor kunci berkembangnya inovasi perdesaan di Jawa Tengah. Penelitian ini bersifat deskriptif kualitatif, dilakukan di 22 desa yang memiliki angka kemiskinan tinggi, namun memiliki potensi sumber daya yang besar. Penelitian melibatkan informan dari unsur kepala desa, perangkat pemerintahan desa, dan perwakilan kelompok masyarakat. Pengumpulan data mengunakan wawancara, kuesioner, FGD. Teknik analisis data menggunakan pendekatan Miles dan Huberman. Kesimpulan penelitian ini adalah: 1) Potensi desa berupa sumber daya alam, manusia, sosial, dan ekonomi yang dikelola dengan cara baru melalui kegiatan wisata, industri kreatif, dan pengolahan produk pascapanen. 2) Inovasi menghadapi kendala keterbatasan ide, minimnya kepeloporan dan jiwa kewirausahaan, keterbatasan pengetahuan dan teknologi, partisipasi masyarakat rendah, serta lemahnya peran lembaga-lembaga desa. 3) Faktor kunci inovasi adalah adanya tokoh pelopor yang berani mengambil risiko, memiliki ide berbeda, didukung pemerintah desa dengan melibatkan stakeholder terkait. 


\section{Pendahuluan}

Undang-undang No 6 Tahun 2014 menempatkan desa sebagai subjek pembangunan yang maju, kuat, mandiri, berkeadilan dan demokratis. Namun demikian, kemiskinan dan keterbelakangan identik dengan kehidupan masyarakat perdesaan, berbeda dengan perkotaan. Kelemahan posisi desa terhadap kota terjadi karena adanya ketidaksetaraan posisi ekonomi yang disebut net capital outflow. Di mana uang/ keuntungan dari sumber daya alam lebih banyak mengalir ke luar dibanding yang masuk ke desa (Rustiadi et al., 2011, p. 141). Desa juga menghadapi keterbatasan akses dibanding perkotaan. Persoalan tersebut menunjukkan struktur perekonomian yang kurang memberikan ruang bagi masyarakat perdesaan untuk berpartisipasi lebih dalam terhadap pelaksanaan pembangunan (Purnomo et al., 2011, p. 64). Desa memiliki banyak sumber daya baik alam, manusia, dan sosial budaya, namun desa menghadapi masalah kemiskinan lebih parah dibanding perkotaan. Di Jawa Tengah angka kemiskinan pada September 2019 sebesar 10,58\% atau sebesar 3.679.400 jiwa. Angka tersebut terdiri dari kemiskinan di perdesaan sebesar 12,26\% atau 2.077.150 jiwa, sedangkan di perkotan $8,99 \%$ atau 1.602.260 jiwa (BPS Jawa Tengah, 2020b).

Jika dilihat dari tingkat pengangguran, di perdesaan hanya sebesar $3,82 \%$ sedangkan perkotaan mancapai 5,14\% (BPS Jawa Tengah, 2020a). Hal ini menunjukkan bahwa hasil yang diperoleh mayarakat desa lebih rendah dibanding perkotaan. Sebanyak 7.130.802 orang atau 32,1 $\%$ masyarakat desa menganggur. Adapun sektor pekerjaan utama adalah petani sebanyak 4.564 .138 orang atau $20,55 \%$, sebanyak 3.286 .164 atau $14,80 \%$ bekerja di sektor swasta, sebanyak 2.250 .757 orang atau $10,13 \%$ sebagai buruh lepas, dan 4.133 .125 orang atau $18,61 \%$ sebagai ibu rumah tangga, dan sisanya bekerja di sektor perdagangan dan jasa (jatengprov.go.id, 2020).

Kondisi tersebut menunjukkan bahwa kemiskinan di desa perlu mendapat perhatian lebih, di mana terjadi dilema banyak sumber daya alam namun kesejahteraan masih tertinggal. Kemiskinan dan pengetahuan yang rendah menyebabkan eksploitasi berlebihan atas sumber daya alam, di mana menurut Satria (Purnomo et al., 2011, p. 66) hal terjadi karena masyarakat desa tergantung pada sumber daya alam.

Program pembangunan yang seharusnya mengangkat derajat hidup orang desa, tetapi di sisi lain juga dapat mendatangkan kerugian bagi desa, di mana justru derajat hidup orang desa tidak bisa terangkat, kemiskinan selalu menjadi masalah yang merupakan komoditas proyek (Eko, 2004, pp. 287-288). Konsep, kebijakan, program, dana dan gerakan terbilang banyak, tetapi sangat miskin visi yang sinergi berbagai pemangku kepentingan desa, bersifat top down, mengabaikan konteks lokal desa, dan menempatkan masyarakat sebagai objek semata. Sebagai salah satu contoh Winarno (2008) menyebutkan bahwa program insentif tidak membuat petani menjadi mandiri, namun justru semakin tergantung dan pragmatis, serta kurangnya pemerataan. Sebagaimana hasil penelitian Prasodjo (2017, p. 39) bahwa adanya otonomi daerah memberikan kebebasan juga kepada desa untuk mengelola potensi lokal sesuai dengan local genius, yang bertujuan memberikan kesejahteraan masyarakat.

Oleh sebab itu, menurut Soleh (2017) pembangunan desa harus mempertimbangkan dan mendasarkan pada potensi yang ada dengan mengedepankan keunggulan masing masing desa, serta memberdayakan partisipasi masyarakat agar merasa memiliki dan bertanggung jawab. Membangun desa juga merupakan proses multidimensional dan melibatkan segenap stakeholder dalam merespons tiga lingkungan desa (alam, budaya dan sosial ekonomi) dengan cara yang tepat (Daldjoeni \& Suyitno, 2004, p. 37).

Inovasi merupakan salah satu kunci penting bagi masyarakat desa untuk menghadapi tantangan tersebut. Sesuai dengan ketentuan UU No 11 Tahun 2019 tentang Sinas Iptek bahwa "Inovasi adalah hasil pemikiran, penelitian, pengembangan, pengkajian, dan/atau penerapan, yang mengandung unsur kebaruan dan telah diterapkan serta memberikan kemanfaatan ekonomi dan/atau sosial (Rustiadi et al., 2011, pp. 125-126), mencontohkan bahwa pada awalnya masyarakat memanfaatkan sumber daya alam namun karena semakin langka, manusia melakuan pengembangan teknologi, atau yang disebut model "induced innovation model".

Pengalaman membuktikan bahwa lahirnya suatu produk baru berawal dari kebutuhan, dan setelah digunakan akan memberikan masukan bagi pengembangan selanjutnya (Zuhal, 2010, p. 33). Selanjutnya Zuhal (2010, p. 77) juga menyatakan bahwa inovasi bermula dari lahirnya gagasan baru yang bermula dari kreativitas. Kekuatan masyarakat dan budayanya merupakan basis dari lahirnya inovasi dan perkembangan peradaban atau yang disebut sebagai knowledge-based society (masyarakat berbasis pengetahuan) sebagai tahapan peradaban manusia tertinggi (Zuhal, 2010).

Pada tahun-tahun terakhir, inovasi mulai diperkenalkan dan menjadi bagian dari pembangunan desa. Suwandana, et.al (2016, p. 467) mendefinisikan desa inovatif di Banten dengan konsep "sebuah desa dapat dikatakan inovatif jika ada produk/jasa yang sangat spesifik dan inovatif yang dihasilkan di desa tersebut, serta keterlibatan masyarakat desa pada kegiatan ekonomi tersebut 
cukup dominan". Penelitian Nurgiarta \& Rosdiana (2019) di Desa Labuhan, Brondong, Lamongan menunjukkan bahwa bina usaha dengan inovasi mampu memberdayakan masyarakat dan meningkatkan pendapatan melalui optimalisasi potensi lokal. Penelitian Yunas (2019) menunjukkan bahwa guna mengembangkan potensi desa secara ideal, maka diperlukan sebuah model inovatif, salah satunya Lumbung Ekonomi Desa.

Inovasi kini menjadi gerakan baru di perdesaan dalam rangka optimalisasi potensi, di mana masyarakat sendiri yang menjadi pelaku, dengan memanfaatkan sumber daya alam, manusia, dan sosial melalui cara baru. Hasil penelitian Hidayah (2018, p. 153) menemukan bahwa pada awalnya masyarakat tidak menyadari mereka memiliki aset dan mengapa harus dipetakan, ketika aset bisa dipetakan, kemudian memunculkan ide masyarakat. Kesadaran tentang aset dan pemanfaatan skill memilki peran penting dalam pemberdayaan inovasi di masyarakat desa, dan langkah ini memerlukan peran fasilitator.

Gambaran di atas menunjukkan bahwa inovasi bisa menjadi salah satu model utama mengatasi masalah desa, yaitu kemiskinan dan ketertinggalan. Inovasi mampu meningkatkan daya saing ekonomi desa, produktivitas dan kualitas produk. Inovasi juga mampu meningkatkan kapasitas SDM dan posisi tawar masyarakat desa melalui berbagai pembaharuan.

Inovasi yang diharapkan dapat mengangkat kesejahteraan masyarakat desa adalah menyangkut pengembangan produk unggulan desa. Beebrapa produk unggulan desa-desa di Jawa Tengah adalah sektor pertanian dan peternakan, industri pengolahan hasil pertanian dan peternakan, perkebunan dan kehutanan, , pengolahan hasil perkebunan, perikanan dan kelautan, serta industri kreatif dan pariwisata. Permasalahan yang perlu dikaji dalam penelitian ini adalah bagaimana agar potensi-potensi tersebut bisa dikembangkan melalui inovasi.

Berdasarkan penjelasan tersebut di atas, penelitian ini dilakukan dengan tujuan untuk: 1) Mengidentifikasi potensi sumber daya perdesaan yang bisa dikembangkan melalui inovasi untuk meningkatkan kesejahteraan masyarakat perdesaan di Jawa Tengah; 2) Mengidentifikasi kendalakendala inovasi perdesaan di Jawa Tengah; 3) Menganalisis faktor-faktor kunci yang mendorong berkembangnya inovasi perdesaan di Jawa Tengah.

\section{Metode}

Penelitian ini bersifat kualitatif. Menurut Sugiyono (2008, pp. 7-9), kualitatif adalah penelitian di mana data yang terkumpul dan analisisnya lebih bersifat kualitatif. Subjek penelitian ini ditentukan secara purposif yaitu desa-desa dengan tingkat kemiskinan tinggi, serta menggambarkan keterwakilan tipologi desa aspek topografi meliputi: (1) desa daerah pegunungan yaitu Desa Slukatan, Mojotengah, Wonosobo; Gunungsari, Pulosari, Pemalang; Desa Babadan, Pagentan, Banjarnegara; Desa Lamuk, Kalikajar, Wonosobo; Desa Slukatan, Mojotengah, Wonosobo. (2) desadataran menengah/perbukitan yaitu Desa Wonoharjo, Rowokele, Kebumen; Desa Karangtengah, Baturraden, Banyumas; Desa Ngargosari, Sumberlawang, Sragen; Desa Karangasem, Bulu, Rembang, Desa Tegalsari, Bruno, Purworejo, Desa Sindangbarang, Karangpucung, Cilacap; Desa Tumanggal, Pengadegan, Purbalingga; Desa Langkap, Kertanegara, Purbalingga; Desa Banjaran, Salem, Brebes; Desa Sikasur, Belik, Pemalang; Desa Balun, Wanayasa, Banjarnegara. (3) desa dataran rendah yaitu Desa Cingkrong, Purwodadi, Grobogan; Desa Sidomulyo, Banjarejo, Blora; Desa Wlahar, Larangan, Brebes, Desa Karangasem, Cawas, Kabupaten Klaten, Desa Krakal, Alian, Kebumen,. (4) desa pesisir atau pantai yaitu Desa Karangmangu, Sarang, Rembang dan Desa Purworejo, Bonang, Demak.

Adapun tipologi desa berdasarkan kegiatan pokoknya meliputi pertanian/agrobisnis, agroindustri, UMKM, industri kreatif dan pariwisata, dan sektor industri, serta jasa. Serta dari aspek aksesibilitas adalah desa terpencil dan pinggiran kota. Informan terdiri dari para pihak yang terkait langsung maupun tidak langsung, yaitu kepala desa dan perangkat pemerintahan desa, Ketua/Anggota Badan Permusyawaratan Desa, unsur masyarakat dari kelompok-kelompok masyarakat, lembaga masyarakat di desa, dan para pelaku usaha.

Teknik pengumpulan data dalam penelitian ini terdiri dari wawancara, FGD, dan pengamatan lapangan, serta dokumen. Adapun teknik analisis data dalam penelitian ini dilakukan dengan pendekatan Miles dan Huberman, yaitu model interaktif dengan adanya 3 kegiatan pengumpulan data, reduksi data, penyajian data dan kesimpulan yang saling terkait (Usman \& Akbar, 2008, p. 88). Pengumpulan data dilakukan dengan pencatatan dan perekaman terhadap hasil wawancara dan FGD yang melibatkan kepala desa dan perangkatnya, tokoh masyarakat, pelaku usaha dan perwakilan organisasi desa (BPD, PKK, Karang Taruna, Pokdarwis, Kelompok Tani, pelaku usaha/UKM), serta ditambah hasil pengamatan langsung. Reduksi data dilakukan dengan melakukan klasifikasi/ pengelompokan sesuai dengan tema-tema bahasan, serta dilakukan verifikasi. Penarikan kesimpulan dilakukan dengan interpretasi terhadap data yang telah diolah sesuai dengan rumusan permasalahan penelitian. 


\section{HASIL DAN PEMBAHASAN}

\section{A. Analisis Potensi Desa}

Bedasarkan data dispermasdesdukcapil 2020, di Jawa Tengah terdapat 7.809 desa yang tersebar di 29 kabupaten dengan karakteristik berbeda menurut wilayah, posisi geografis dan jumlah penduduk. Berdasarkan usia, tercatat kelompok tertinggi adalah usia produktif antara 15 - 64 tahun sebesar 71,81\%, usia 15 tahun ke bawah $23 \%$, dan usia di atas 65 tahun hanya 5,17\%. Dari tingkat pendidikan, terbanyak adalah lulusan SD sebesar 33,54\%. Kemudian lulusan SLTP sebesar $16,60 \%$ dan lulsuan SLTA sebesar 15\%. Sedangkan penduduk yang lulus DIII hanya sebesar 0,93\% dan lulus Sarjana/DIV sebesar 2,48\%.

Lokasi penelitian berada di 22 desa dari 152 desa priortitas penanggulangan kemiskinan di 15 kabupaten di Jawa Tengah. Desa-desa tersebut memiliki angka kemiskinan tinggi, namun memiliki potensi produktif untuk dikembangkan. Lokasi desa yang dipilih juga mempertimbangkan karakteristik wilayah, yaitu di pegunungan, di perbukitan/dataran

Tabel 1.

Potensi Desa di Kawasan Pegunungan/Dataran Tinggi

\begin{tabular}{|c|c|c|c|c|c|}
\hline Potensi & Gunungsari & Babadan & Lamuk & Slukatan & Balun \\
\hline $\begin{array}{l}\text { Bentang } \\
\text { alam }\end{array}$ & $\begin{array}{l}\text { lereng Gunung } \\
\text { Slamet, hutan }\end{array}$ & $\begin{array}{l}\text { Kawasan Dieng, air } \\
\text { terjun }\end{array}$ & $\begin{array}{l}\text { Lereng gunung } \\
\text { Sumbing, }\end{array}$ & $\begin{array}{l}\text { lereng Gunung } \\
\text { Bismo, }\end{array}$ & $\begin{array}{l}\text { Dataran tinggi, , } \\
\text { hutan }\end{array}$ \\
\hline Lahan : & $\begin{array}{l}\text { Perkebunan } \\
\text { warga, lahan } \\
\text { perhutani }\end{array}$ & Lahan warga subur & $\begin{array}{l}\text { Lahan warga subur, } \\
\text { lahan perhutani }\end{array}$ & $\begin{array}{l}\text { Lahan warga subur, } \\
\text { lahan hutan }\end{array}$ & $\begin{array}{l}\text { Lahan warga subur, } \\
\text { lahan perhutani }\end{array}$ \\
\hline Air & Kesulitan air baik & $\begin{array}{l}\text { Sumber air men- } \\
\text { cukupi, mata air, } \\
\text { sungai \& air terjun }\end{array}$ & $\begin{array}{l}\text { Ada sumber air } \\
\text { melimpah }\end{array}$ & $\begin{array}{l}\text { Sumber air bagus, } \\
\text { air terjun, sendang/ } \\
\text { mata air }\end{array}$ & $\begin{array}{l}\text { Ketersediaan air } \\
\text { cukup, air terjun }\end{array}$ \\
\hline Akses & $\begin{array}{l}\text { Jalur wisata, jalan } \\
\text { menuju desa agak } \\
\text { sulit }\end{array}$ & $\begin{array}{l}\text { Aksesibilitas } \\
\text { lumayan sulit, } \\
\text { terpencil }\end{array}$ & $\begin{array}{l}\text { Aksesibilitas cukup } \\
\text { mudah }\end{array}$ & $\begin{array}{l}\text { Aksesibilitas } \\
\text { lumayan sulit, ter- } \\
\text { pencil }\end{array}$ & $\begin{array}{l}\text { Aksesibilitas cukup } \\
\text { baik, jalur wisatsa }\end{array}$ \\
\hline Pertanian & $\begin{array}{l}\text { kopi arabica, } \\
\text { tanaman kayu, } \\
\text { hortikultura }\end{array}$ & $\begin{array}{l}\text { kopi arabica, tem- } \\
\text { bakau, sayuran }\end{array}$ & $\begin{array}{l}\text { sayur, tembakau, } \\
\text { kopi arabica, ternak }\end{array}$ & $\begin{array}{l}\text { sayur, tembakau, } \\
\text { dan kopi arabica, }\end{array}$ & $\begin{array}{l}\text { sayur, tembakau, } \\
\text { kopi arabica, } \\
\text { ternak }\end{array}$ \\
\hline UMKM & $\begin{array}{l}\text { Olahan pangan, } \\
\text { olahan kopi }\end{array}$ & $\begin{array}{l}\text { Olahan makanan, } \\
\text { olahan kopi }\end{array}$ & $\begin{array}{l}\text { Olahan } \\
\text { makanan,olahan } \\
\text { kopi }\end{array}$ & $\begin{array}{l}\text { Olahan makanan, } \\
\text { olahan kopi }\end{array}$ & $\begin{array}{l}\text { Olahan makanan, } \\
\text { olahan kopi }\end{array}$ \\
\hline $\begin{array}{l}\text { Wisata, } \\
\text { Jasa, } \\
\text { Industri } \\
\text { Kreatif }\end{array}$ & $\begin{array}{l}\text { Baru akan merin- } \\
\text { tis wisata edukasi } \\
\text { perkebunan kopi }\end{array}$ & $\begin{array}{l}\text { Akan mengem- } \\
\text { bangkan wisata } \\
\text { alam, air terjun, } \\
\text { kawasan perdesaan }\end{array}$ & $\begin{array}{l}\text { Akan mengembang- } \\
\text { kan wisata alam; air, } \\
\text { tracking, pendakian, } \\
\text { pengolahan kopi }\end{array}$ & $\begin{array}{l}\text { Pendakian gunung } \\
\text { Bismo (komunitas), } \\
\text { akan mengembang- } \\
\text { kan objek sumber } \\
\text { air, tracing, dll }\end{array}$ & $\begin{array}{l}\text { Akan kembangkan } \\
\text { wisata air terjun }\end{array}$ \\
\hline $\begin{array}{l}\text { Kesenian/ } \\
\text { Adat }\end{array}$ & $\begin{array}{l}\text { Kuda lumping, } \\
\text { kuntulan }\end{array}$ & & Ritual adat & & Ritual adat \\
\hline $\begin{array}{l}\text { Kelem- } \\
\text { bagaan }\end{array}$ & $\begin{array}{l}\text { BUMDes belum } \\
\text { punya usaha, } \\
\text { Kelompok Pengo- } \\
\text { lah Kopi }\end{array}$ & $\begin{array}{l}\text { Kelompok tani } \\
\text { kopi, Pokdarwis } \\
\text { tidak aktif, embrio } \\
\text { BUMDes }\end{array}$ & $\begin{array}{l}\text { BUMDes merintis } \\
\text { usaha pengolahan } \\
\text { sampah, ternak, } \\
\text { Pamsimas }\end{array}$ & $\begin{array}{l}\text { Kelompok pengelola } \\
\text { pendakian, } \\
\text { pokdarwis akan } \\
\text { dibentuk }\end{array}$ & $\begin{array}{l}\text { Belum ada kelem- } \\
\text { bagaan (BUMDes, } \\
\text { olahan kopi, pok- } \\
\text { darwis) }\end{array}$ \\
\hline
\end{tabular}

Sumber: Data primer (2019) sedang, dataran rendah, dan kawasan pantai, baik yang kategori desa di pelosok maupun sub urban. Pengelompokkan berdasarkan karakteristik alam ini dilakukan mengingat adanya kecenderungan kehidupan dan mata pencaharian masyarakat desa sangat erat hubungannya dengan alam (Jamaludin, 2017, p. 26).

Secara umum SDA di pegunungan memiliki kekuatan untuk dimanfaatkan sebagai lahan pertanian hortikultura, tanaman perkebunan, serta atraksi wisata, seperti jelajah, pendakian, pemandangan alam, hutan, atau wisata edukasi. Lahan pertanian milik warga biasanya ditanami sayuran, buah, atau tanaman perkebunan (kopi, tembakau). Adapun lahan hutan, sebagian besar milik Perhutani berupa tanaman kayu di mana bagian bawahnya bisa ditanami tanaman perkebunan seperti kopi, serta memiliki potensi wahana wisata alam.

Desa-desa di kawasan perbukitan/dataran sedang memiliki ciri umum tersedianya lahan hutan, bentang alam perbukitan yang bisa dikembangkan untuk berbagai aktivitas baik pertanian, maupun 
Tabel 2.

Potensi Desa di Kawasan Perbuktian/Dataran Menengah

\begin{tabular}{|c|c|c|c|c|c|}
\hline Potensi & Ngargosari & Karangasem & Sindangbarang & Wonoharjo & Tumanggal \\
\hline Bentang alam & $\begin{array}{l}\text { Perbukitan seki- } \\
\text { tar waduk }\end{array}$ & $\begin{array}{l}\text { Perbukitan batu ka- } \\
\text { rang \& kapur. Goa }\end{array}$ & $\begin{array}{l}\text { Perbukitan, } \\
\text { hutan jati }\end{array}$ & $\begin{array}{l}\text { perbukitan, hutan, } \\
\text { sumber air (air } \\
\text { terjun) }\end{array}$ & $\begin{array}{l}\text { perbukitan, } \\
\text { ladang, ada sum- } \\
\text { ber air }\end{array}$ \\
\hline Lahan : & $\begin{array}{l}\text { Lahan tadah hu- } \\
\text { jan, perhutani }\end{array}$ & $\begin{array}{l}\text { Lahan tadah hujan, } \\
\text { lahan perhutani }\end{array}$ & $\begin{array}{l}\text { Tadah hujan, } \\
\text { lahan perhutani }\end{array}$ & $\begin{array}{l}\text { Lahan subur (te- } \\
\text { galan dan sawah), } \\
\text { perhutani }\end{array}$ & $\begin{array}{l}\text { Ladang cukup } \\
\text { subur }\end{array}$ \\
\hline Air & $\begin{array}{l}\text { Agak } \\
\text { kekurangan air }\end{array}$ & $\begin{array}{l}\text { Ada sumber air, } \\
\text { debit kecil }\end{array}$ & $\begin{array}{l}\text { Agak kering, } \\
\text { namun cukup }\end{array}$ & $\begin{array}{l}\text { Cukup tersedia, ada } \\
\text { sumber air }\end{array}$ & Cukup air \\
\hline Akses & Cukup mudah & Cukup mudah & Mudah & Sangat mudah & Cukup mudah \\
\hline Pertanian : & $\begin{array}{l}\text { Palawija, kayu, } \\
\text { ternak, }\end{array}$ & $\begin{array}{l}\text { Palawija, tembakau, } \\
\text { padi, kayu }\end{array}$ & $\begin{array}{l}\text { Palawija, sawah, } \\
\text { ternak (kambing } \\
\text { etawa) }\end{array}$ & $\begin{array}{l}\text { Tanaman pangan } \\
\text { (padi, palawija), } \\
\text { buah, kayu }\end{array}$ & $\begin{array}{l}\text { Palawija, padi, } \\
\text { kayu }\end{array}$ \\
\hline UMKM & $\begin{array}{l}\text { Olahan makanan, } \\
\text { olahan ikan, } \\
\text { kuliner, kerajinan }\end{array}$ & Olahan makanan & $\begin{array}{l}\text { Olahan makanan, } \\
\text { peternakan dom- } \\
\text { ba/ susu domba }\end{array}$ & $\begin{array}{l}\text { Olahan makanan, } \\
\text { kerajinan, }\end{array}$ & $\begin{array}{l}\text { Olahan makanan, } \\
\text { bulu mata, pe- } \\
\text { mintalan benang }\end{array}$ \\
\hline $\begin{array}{l}\text { Wisata, Jasa, } \\
\text { Industri Kreatif }\end{array}$ & $\begin{array}{l}\text { Wisata sekitar } \\
\text { waduk, jasa } \\
\text { wisata }\end{array}$ & $\begin{array}{l}\text { Potensi wisata } \\
\text { ziarah }\end{array}$ & $\begin{array}{l}\text { Agrowisata, } \\
\text { Aanyaman, }\end{array}$ & $\begin{array}{l}\text { Potenai wisata alam, } \\
\text { edukasi, adat, dan } \\
\text { budaya }\end{array}$ & $\begin{array}{l}\text { Pasar wisata } \\
\text { (rencana) }\end{array}$ \\
\hline Kesenian/Adat & Wisata ziarah & $\begin{array}{l}\text { Ritual, ziarah (goa } \\
\text { beduk, mata air, } \\
\text { petilasan) }\end{array}$ & $\begin{array}{l}\text { Kesenian, kam- } \\
\text { pung pancasila }\end{array}$ & $\begin{array}{l}\text { Tradisi kagamaan } \\
\text { Islam, Budha (med- } \\
\text { itasi) }\end{array}$ & \\
\hline Kelembagaan & $\begin{array}{l}\text { BUMDes akan } \\
\text { kelola wisata }\end{array}$ & $\begin{array}{l}\text { BUMDes belum ak- } \\
\text { tif, pokdarwis belum } \\
\text { terbentuk }\end{array}$ & $\begin{array}{l}\text { BUMDes tetapi } \\
\text { kurang aktif }\end{array}$ & $\begin{array}{l}\text { Ada BUMDes, } \\
\text { Pokdarwis, LSM @ } \\
\text { worm (edukasi) }\end{array}$ & $\begin{array}{l}\text { BUMDes, akan } \\
\text { membuka pasar } \\
\text { wisata }\end{array}$ \\
\hline Potensi & Tegalsari & Langkap & Banjaran & Sikasur & Karangtengah \\
\hline Bentang alam & $\begin{array}{l}\text { Perbukitan dan } \\
\text { persawahan, } \\
\text { terpencil }\end{array}$ & $\begin{array}{l}\text { Kawaan perbuki- } \\
\text { tan, hutan, sawah } \\
\text { tegalan }\end{array}$ & $\begin{array}{l}\text { Bukti dan } \\
\text { lembah, ladang, } \\
\text { sawah, hutan, }\end{array}$ & $\begin{array}{l}\text { Lereng Gunung } \\
\text { Slamet bagian } \\
\text { bawah, sungai }\end{array}$ & $\begin{array}{l}\text { Lereng Gunung } \\
\text { Slamet bagian } \\
\text { bawah }\end{array}$ \\
\hline Lahan & $\begin{array}{l}\text { Swah dan tegalan } \\
\text { subur }\end{array}$ & $\begin{array}{l}\text { Lahan subur, per- } \\
\text { hutani, hutan }\end{array}$ & $\begin{array}{l}\text { Lahan subur, per- } \\
\text { bukitan, sawah, } \\
\text { hutan }\end{array}$ & $\begin{array}{l}\text { Sawah subur, } \\
\text { tegalan, }\end{array}$ & $\begin{array}{l}\text { Sawah subur, } \\
\text { hutan, perhutani, } \\
\text { ladang/tegalan }\end{array}$ \\
\hline Air & Cukup melimpah & Cukup tersedia & $\begin{array}{l}\text { Secara umum } \\
\text { tercukupi }\end{array}$ & Sangat melimpah & Sangat cukup \\
\hline Akses & $\begin{array}{l}\text { Agak sulit, jauh } \\
\text { dari pusat kota, } \\
\text { terpencil }\end{array}$ & $\begin{array}{l}\text { Cukup terjangkau, } \\
\text { jalan bagus }\end{array}$ & $\begin{array}{l}\text { Sedikit terpen- } \\
\text { cil, terkurung } \\
\text { pegunungan }\end{array}$ & Sanga mudah & Sangat mudah \\
\hline Pertanian : & $\begin{array}{l}\text { Padi, palawija, } \\
\text { buah-buahan } \\
\text { (pisang, durian, } \\
\text { jambu, kelapa), } \\
\text { ternak }\end{array}$ & $\begin{array}{l}\text { Padi, palawija, kayu, } \\
\text { ternak, hasil hutan }\end{array}$ & $\begin{array}{l}\text { Palawija, padi, } \\
\text { kayu, buah, ter- } \\
\text { nak, hortikultura }\end{array}$ & $\begin{array}{l}\text { Sawah, palawija, } \\
\text { perikanan, hortikul- } \\
\text { tura, ternak }\end{array}$ & $\begin{array}{l}\text { Padi, palawija, } \\
\text { perikanan, bu- } \\
\text { didaya tanaman } \\
\text { hias, buah, sayur, } \\
\text { kayu, bambu }\end{array}$ \\
\hline UMKM & $\begin{array}{l}\text { Olahan makan, } \\
\text { perdagangan } \\
\text { (dekat pasar) }\end{array}$ & Olahan makanan & $\begin{array}{l}\text { Olahan makanan, } \\
\text { perdagangan, } \\
\text { kuliner, kerajinan }\end{array}$ & $\begin{array}{l}\text { Olahan nanas, olah- } \\
\text { an makanan }\end{array}$ & $\begin{array}{l}\text { Olahan makanan, } \\
\text { perdagangan, }\end{array}$ \\
\hline $\begin{array}{l}\text { Wisata, Jasa, } \\
\text { Industri Kreatif }\end{array}$ & $\begin{array}{l}\text { Pertukangan, , } \\
\text { olahan limbah } \\
\text { (pertanian, pasar, } \\
\text { rumah tangga) }\end{array}$ & $\begin{array}{l}\text { Potensi wisata alam, } \\
\text { wisata minat khu- } \\
\text { sus, wisata edukasi, } \\
\text { kerajinan }\end{array}$ & $\begin{array}{l}\text { Potensi wistaa } \\
\text { alam, adat } \\
\text { budaya, kerajinan } \\
\text { (anyaman) }\end{array}$ & $\begin{array}{l}\text { Pariwisata berbasis } \\
\text { air (curug, telaga), } \\
\text { kerajinan }\end{array}$ & $\begin{array}{l}\text { Kerajinan bambu, } \\
\text { batok kelapa, } \\
\text { kain, dan kayu }\end{array}$ \\
\hline Kesenian/Adat & Sedekah bum & Kesenian lokal & $\begin{array}{l}\text { Tradisi, adat } \\
\text { budaya sunda }\end{array}$ & Tradisi ritual adat & \\
\hline Kelembagaan & $\begin{array}{l}\text { Embrio UMDes, } \\
\text { Kelompok tani, } \\
\text { PKK }\end{array}$ & $\begin{array}{l}\text { BUMDes, Pokdarwis } \\
\text { belum dibentuk }\end{array}$ & $\begin{array}{l}\text { BUMDes, Pok- } \\
\text { darwis }\end{array}$ & $\begin{array}{l}\text { Ada BUMDes, ada } \\
\text { Pokdarwis }\end{array}$ & $\begin{array}{l}\text { BUMDes belum } \\
\text { ada, PKK }\end{array}$ \\
\hline
\end{tabular}

Sumber: Data primer (2019)

Potensi Inovasi untuk Meningkatkan Kesejahteraan Masyarakat Desa 
wisata. Beberapa desa sudah melakukan upaya pemanfaatan lahan hutan terutama milik perhutani untuk dikembangkan pemanfaatannya.

Di perdesaan dataran rendah yang utama adalah lahan pertanian sawah di mana sebagian memiliki sumber air yang mencukupi karena adanya saluran irigasi atau sungai, namun sebagian merupakan lahan tadah hujan atau cenderung kering. Sebagian besar ditanami padi, serta berbagai komoditas palawija seperti jagung, kedelai, kacang hijau, dan singkong/ubi.

Adapun di kawasan pesisir memiliki sumber daya alam pantai dan laut, terutama di bidang perikanan, dan ekosistem pantai yang bisa dimanfaatkan untuk berbagai kegiatan produktif. Selain budidaya perikanan, ekosistem pantai juga bisa dimanfaatkan sebagai atraksi wisata baik wisata konvensional maupun wisata minat khusus.

Dari aspek sumber daya manusia, di desadesa lokasi penelitian, kemampuan inovasi masih dalam tahap embrio, di mana sebagian besar masih merintis beberapa inovasi pemafaatan sumber daya alam. Namun beberapa hal terlupakan seperti skill, pengetahuan lokal dan beberapa ilmu tradisional dianggap bukan suatu sumber daya. Perlunya menekankan bahwa skill dan pengetahuan lokal justru menjadi modal untuk melakukan inovasi.

Sesuai dengan apa yang disampaikan Jamaludian (2017, p. 89) bahwa kemajuan teknologi menyebabkan perubahan sosial ekonomi masyarakat desa, fenomena tersebut juga terjadi di semua lokasi penelitian. Saat ini tumbuh kesadaran memanfaatkan potensi alam untuk kegiatan wisata seperti wisata alam, pendakian, edukasi, di mana mereka tidak hanya menjual bahan pangan secara langsung, namun mengembangkan layanan wisata alam dilengkapi dengan produk-produk lokal.

Ciri umum lainnya di perdesaan adalah banyaknya orang merantau mengharapkan penghasilan lebih baik di perkotaan. Kecenderungan sebagian orang desa menganggap sulit mendapatkan pekerjaan di desa sehingga berurbanisasi ke kota (Jamaludin, 2017, p. 187). Di desa mereka tidak memiliki sumber daya seperti lahan, sehingga memilih menjadi pekerja di perkotaan baik sebagai buruh pabrik, konstruksi, perdagangan atau jasa

Tabel 3.

Potensi Desa di Kawasan Dataran Rendah

\begin{tabular}{|c|c|c|c|c|c|}
\hline Potensi & Sidomulyo & Wlahar & Karangasem & Cingkrong & Krakal \\
\hline Bentang alam & $\begin{array}{l}\text { lahan pertanian } \\
\text { tadah hujan dan } \\
\text { hutan jati. }\end{array}$ & $\begin{array}{l}\text { kawasan pertanian } \\
\text { dataran rendah }\end{array}$ & $\begin{array}{l}\text { Dataran rendah per- } \\
\text { dawahan tadah hujan }\end{array}$ & $\begin{array}{l}\text { Perswawhan di } \\
\text { pingiran kota }\end{array}$ & $\begin{array}{l}\text { Persawahan, } \\
\text { lembah }\end{array}$ \\
\hline Lahan & $\begin{array}{l}\text { Sawah tadah } \\
\text { hujan,perhutani }\end{array}$ & $\begin{array}{l}\text { Sawah tadah hujan, } \\
\text { ladang perkebunan } \\
\text { sereh }\end{array}$ & Sawah tadah hujan & Lahan tadah hujan & $\begin{array}{l}\text { Sawah, tadah } \\
\text { hujan, tegalan }\end{array}$ \\
\hline Air & Keterbatasan air & $\begin{array}{l}\text { Agak kekurangan di } \\
\text { musim kemaarau }\end{array}$ & $\begin{array}{l}\text { Kekuraangan air, } \\
\text { terutama di musim } \\
\text { kemarau }\end{array}$ & $\begin{array}{l}\text { Kurang di musim } \\
\text { kemarau, banjir } \\
\text { di musim hujan, } \\
\text { embung alami }\end{array}$ & $\begin{array}{l}\text { Cukup terse- } \\
\text { dia sumber air }\end{array}$ \\
\hline Akses & $\begin{array}{l}\text { Agak sulit, jauh } \\
\text { dari pusat kota, } \\
\text { terpencil }\end{array}$ & $\begin{array}{l}\text { Cukup mudah, } \\
\text { berada di jalur } \\
\text { alternatif }\end{array}$ & Lumayan mudah & Sangat mudah & Mudah \\
\hline Pertanian : & $\begin{array}{l}\text { Padi, palawija, } \\
\text { kayu, ternak }\end{array}$ & Padi, sereh, ternak & Padi, palawija & $\begin{array}{l}\text { Padi, palawija, sayur, } \\
\text { buah, ternak }\end{array}$ & $\begin{array}{l}\text { Palawija, padi, } \\
\text { kayu }\end{array}$ \\
\hline UMKM & Olahan makanan & $\begin{array}{l}\text { Olahan makanan, } \\
\text { olahan minyak } \\
\text { sereh, olahan } \\
\text { kerupuk }\end{array}$ & Olahan makanan & $\begin{array}{l}\text { Olahan makanan, } \\
\text { perdagangan }\end{array}$ & $\begin{array}{l}\text { Industri } \\
\text { tahu, olahan } \\
\text { makanan, } \\
\text { perdagangan }\end{array}$ \\
\hline $\begin{array}{l}\text { Wisata, Jasa, } \\
\text { Industri Kreatif }\end{array}$ & $\begin{array}{l}\text { kerajinan } \\
\text { berbahan kayu, } \\
\text { batok kelapa, dan } \\
\text { bamboo }\end{array}$ & & Pamsimas, pasar desa & $\begin{array}{l}\text { Wisata memanfaat- } \\
\text { kan embung }\end{array}$ & $\begin{array}{l}\text { Biji genitri, } \\
\text { industri genitri }\end{array}$ \\
\hline \multicolumn{6}{|l|}{ Kesenian/Adat } \\
\hline Kelembagaan & $\begin{array}{l}\text { Kelompok pemu- } \\
\text { da, belum ada } \\
\text { BUMDes }\end{array}$ & $\begin{array}{l}\text { Karang taruna, } \\
\text { kelompok tani, PKK }\end{array}$ & Pengelola Pamsimas & $\begin{array}{l}\text { Ada BUMDes dan } \\
\text { pengeloal wisata } \\
\text { embung }\end{array}$ & Kelompok PKK \\
\hline
\end{tabular}

Sumber: Data primer (2019) 
Tabel 4.

Potensi Desa di Kawasan Pesisir

\begin{tabular}{|c|c|c|}
\hline Potensi & Desa Purworejo & Desa Karangmangu \\
\hline Bentang alam & $\begin{array}{l}\text { Kawasan rawan banjir rob sehingga sebagian } \\
\text { besar infrastruktur rusak }\end{array}$ & $\begin{array}{l}\text { Terlatak di jalur utama pantura jawa dengan akse } \\
\text { trasportasi yang baik }\end{array}$ \\
\hline Lahan & Tambak, pantai, terendam rob & Jalur jalan raya, pantai \\
\hline Air & Kualitas air buruk & Relatif terpenuhi \\
\hline Akses & Akses sulit karena terhalang air rob & Sangat mudah, terletak di jalur utara pantura \\
\hline Pertanian & Perikanan tangkap & Perikanan tangkap, budidaya (tambak) \\
\hline UMKM & Olahn ikan, perdagangan, jasa & Olahan ikan, perdagangan, jasa \\
\hline $\begin{array}{l}\text { Wisata, Jasa, Industri } \\
\text { Kreatif }\end{array}$ & Pengolahan ikan, galangan perahu & $\begin{array}{l}\text { Potensi menbuat pasar ikan (pasar pantai) atau } \\
\text { rest area, olahan ikan }\end{array}$ \\
\hline \multicolumn{3}{|l|}{ Kesenian/Adat } \\
\hline Kelembagaan & Belum ada BUMDes, PKK & Ada BUMDes tetapi belum aktif \\
\hline
\end{tabular}

Sumber: Data primer (2019)

lainnya. Sebagian juga bergerak di bidang UMKM, olahan makanan, penyediaan bahan baku atau industri rumahan lainnya. Selain itu merantau juga dilakukan oleh mereka yang memiliki pendidikan tinggi, dikarenakan menganggap pekerjaan sektor pertanian di desa tidak mampu menghasilkan pendapatan besar. Namun demikian, di beberapa desa sekarang ini banyak komunitas pemuda terpelajar yang pulang ke desa dan berusaha membangun desanya. Adanya fenomena sarjana pulang ke desa memberikan harapan pebaikan kualitas SDM di desa.

Kemudian sumber daya sosial merupakan sarana penguat dan penopang dari fungsi manusia dalam berkreasi dan berinovasi. Peran tokoh seperti kepala desa, tokoh masyarakat, tokoh adat, tokoh agama cukup penting. Di kawasan perdesaan pegunungan, perbukitan, atau desa di pelosok, peran tokoh ini sangat besar, sedangkan di kawasan pantai atau mendekati perkotaan, sudah mulai memudar. Tokoh masyarakat formal maupun informal memberi peran penting dalam membangun partisipasi terutama para pemuda (Kusnadi \& Iskandar, 2017, p. 362).

Di kawasan pegunungan secara umum para tokoh masih memegang berbagai tatanan sosial tradisional, di mana peran tokoh masyarakat, tokoh adat, tokoh agama, dan kepala desa masih tinggi. Pihak-pihak tersebut masih ditaati oleh sebagian besar masyarakat. Tradisiadat seperti sedekah bumi, ziarah, suro atau peringatan lain kerap digelar di kawasan ini. Oleh sebab itu, perubahan-perubahan sosial memerlukan peran atau dukungan, atau paling tidak persetujuan dari tokoh-tokoh tersebut. Namun demikian, peran tokoh-tokoh pemuda juga cukup penting sebagai pembawa perubahan atau pembaharuan. Di kawasan dataran rendah ritual dan tradisi tidak kental sebagaimana di kawasan pegunungan, masyarakat di kawasan ini cukup longgar dan relatif menerima berbagai perubahan. Interaksi dengan perkotaan juga menjadikan mereka lebih pragmatis. Mereka lebih memilih halhal yang praktis dan langsung menghasilkan. Peran tokoh masyarakat, tokoh agama, kepala desa atau perangkat tidak sekuat di wilayah-wilayah lain. Di kawasan pesisir solidaritas yang cukup tinggi, namun juga rawan konflik.

Sumber daya ekonomi merupakan sarana yang digunakan untuk menggerakkan inovasi dan kreasi, sebagai media aktivitas riil masyarakat desa. Sumber daya yang terdiri dari kapasitas modal, ketersediaan sarana produksi, aktivitas produksi yang sudah berjalan, jaringan pasar, dan lembagalembaga ekonomi merupakan sebab dan juga dampak serta pelaku berjalannya sebuah inovasi itu sendiri. Kegiatan utama ekonomi desa sesuai konsep Kementerian Dalam Negeri terbagi menjadi agraris, industri/kerajinan, dan perdagangan dan jasa (Jamaludin, 2017, p. 190).

Di kawasan pegunungan/dataran tinggi, terdiri aktivitas dari sektor pertanian dalam arti luas (hortikultura, perkebunan, kehutanan, peternakan), UMKM olahan hasil panen dan olahan pangan, serta industri atau jasa wisata dan industri kreatif. Di kawasan dataran sedang lebih banyak ke pertanian lahan kering seperti palawija, beberapa jenis buahbuahan tropis, beberapa jenis sayuran, tanaman kayu, ternak (kambing, domba, sapi). Di dataran rendah sektor yang utama antara lain pertaian tanaman pangan terutama padi diselingi palawija, beberapa jenis sayur dan buah, serta peternakan (sapi, ayam, kambing) yang digunakan sebagai tabungan. Adapun di kawasan pesisir lebih banyak eksplorasi laut dan ekosistem pantai. Perikanan tangkap dan budidaya, serta pengolahan ikan merupakan inti dari perekonomian desa-desa ini. 
Secara umum, aktifitas ekonomi di banyak desa juga tumbuh UMKM baik mengolah hasil panen sebagai bahan baku, maupun olahan makanan untuk konsumsi. UMKM ini bisanya mengolah berbagai jenis bahan pangan yang dihasilkan dari sekitar atau bahan baku lokal. Jenis olahan tergantung dari ketersediaan bahan baku di kawasan tersebut. Sebagian besar mereka mengolah hasil panen atau olahan makanan, olahan hasil ternak, olahan hasil hutan, kerajinan bahan lokal.

Sumber daya ekonomi potensial lainnya adalah potensi kegiatan pariwisata yang bisa dikembangkan dimana saat ini sedang diminati di hampir semua desa, dengan memanfaatkan bentang alam berupa pemandangan, air terjun, bukit, hutan, atau objek alam lainnya. Kegiatan ini lebih banyak dimotori oleh generasi muda dengan memafaatkan media sosial sebagai sarana pemasarannya.

Kegiatan ekonomi juga didukung oleh keberadaan lembaga-lembaga di tingkat desa seperti kelompok tani, koperasi, PKK, dan pemuda. Selain itu hampir semua desa sedang mengupayakan tumbuhnya Badan Usah Milik Desa (BUMDes). BUMDes biasanya memiliki beberapa unit usaha antara lain pengolahan kopi, pengelolaan pamsimas (air bersih), pengelolaan sampah, pengelolaan wisata, dan kios desa. Saat ini belum semua desa memiliki BUMDes yang aktif dikarenakan terkendala permodalan, sarpras dan SDM pengelola.

Aspek pendukung ekonomi lainnya yang berpengaruh terhadap desa di kawasan ini adalah aksesibilitas. Di satu sisi, dengan aksesibilitas yang baik, kawasan pegunungan/dataran tinggi memiliki potensi yang tinggi baik dalam distribusi barang dan jasa, maupun menarik minat orang untuk berkunjung. Sedangkan bagi daerah yang kondisi infrastruktut terbatas memiliki hambatan dalam arus barang/jasa, dan minat berkunjung, meskipun pada beberapa kasus justru menarik minat kelompok tertentu/minat khusus. Lebih dari separuh desa di kawasan ini aksesibilitasnya memang tidak terlalu baik.

\section{B. Kendala-Kendala Inovasi di Desa}

Berdasarkan penggalian daa lapangan terkait kondisi desa-desa tersebut di atas, ada beberapa persoalan yang dihadapi pemangku kepentingan dalam mengembangkan inovasinya. Beberapa permaslaahan sebagaimana tergambarkan di bawah ini.

Berdasarkan penjelasan di atas, dapat dikategorikan menjadi persoalan manajerial sumber daya alam, SDM, sosial, sumber daya ekonomi, kelembagaan, dan sarana prasarana. Sesuai dengan hasil penelitian Sunarjaya, dkk (2018, pp. 224-225) bahwa faktor-faktor ketidakberhasilan pengembangan desa adalah belum jelasnya program kerja, infastruktur dan tata ruang, serta kurangnya fasilitasi pihak terkait.
Dari aspek manajerial sumber daya alam kebanyakan desa memiliki sumber daya alam melimpah, namun belum begitu dipahami dengan baik oleh masyarakatnya. Sebagian kecil sudah memahami, namun masih belum menemukan ide untuk mengolahnya. Selain itu sebagian besar mereka juga belum berani melakukan eksplorasi.

Dari aspek SDM, sebagian besar masih belum memahami bahwa apa yang dimilikinya merupakan potensi yang bernilai apabila dikelola dengan cara baru. Masih ada keraguan untuk berinovasi. Di dalam pengembangan produk, juga masih terbatas ide-ide yang dimiliki, seperti untuk olahan masih kurang penguasaan teknologi, sentra olahan dan perluasan potensi pasar. Untuk wisata juga belum memiliki pemahaman tentang konsep pengembangan desa wisata yang memanfaatkan berbagai potensi desa. Selain itu kepedulian terhadap potensi alam, dan lingkungan rendah, belum memiliki pemahaman pasar yang baik, serta lemahnya kelembagaan pengembangan potensi ekonomi desa. Secara umum masyarakat juga perlu ditingkatkan kepeloporan dan jiwa kewirausahaannya.

Dari aspek penguasaan teknologi, terdapat kendala dimana penguasaan teknologi terbatas, sedangkan kebutuhan terhadap teknologi di perdesaan cukup luas, karena sektornya sangat beragam. Kebutuhan teknologi di perdesaan tidak semua dapat dijawab oleh sumber daya iptek di Jawa Tengah sesuai dengan harapan. Oleh karena itu dilakukan kompromi terhadap kebutuhan teknologi atau memanfaatkan jejaring.

Dari aspek sosial, beberapa desa menghadapi masalah partisipasi masyarakat, pemerintah desa yang kurang tanggap, serta relasi yang kurang seimbang antara masyarakat dan pemerintah desa. Ada kesan kebijakan tergantung dari ide kepala desa atau perangkat desa, sehingga masyarakat hanya menjadi pengikut. Masyarakat juga masih tergantung pada figur pimpinan, sehingga setiap perubahan atau inovasi memerlukan peran tokohtokoh masyarakat. Kehadiran seorang pionir atau pelopor sangat diperlukan dengan wujud keberhasilannya dalam rangka memberikan dorongan bagi budaya inovasi tersebut. Kebanyakan masyarakat harus melihat contoh yang berhasil sebelum menerima ide baru, sehingga kreativitas dan inovasi masih rendah.

Dari aspek sumber daya ekonomi, beberapa kendala yang dihadapi oleh perdesaan adalah keterbatasan lapangan kerja karena keterbatasan penguasaan lahan lahan, lahan kurang subur, kurang kreatifitas, atau sektor pekerjaan diangap kurang menarik. Selain itu semangat untuk berusaha rendah, mereka lebih senang menjadi pekerja. Di sektor pertanian, peternakan dan UMKM juga mengalami kendala penguasaan teknologi dan peralatan yang terbatas. Mereka lebih senang langsung menjual bahan mentah untuk menghasilkan uang, tanpa 
Tabel 5.

Kendala-kendala Inovasi di Desa

\begin{tabular}{|c|c|c|}
\hline No & Desa & Kendala \\
\hline 1 & Gunungsari & Jiwa kewirausahaan kurang, mengharapkan bantuan, kesulitan air, BUMDes masih lamban \\
\hline 2 & Babadan & $\begin{array}{l}\text { Kebingungan konsep, keterbatasan ide dan kreasi, jaringan pemasaran produk lokal. Kesulitan } \\
\text { akses masuk ke desa }\end{array}$ \\
\hline 3 & Lamuk & $\begin{array}{l}\text { Kelembagaan pengelolaan desa wisata (Pokdarwis) dan BUMDes belum aktif, masih minimnya } \\
\text { pengetahuan konsep desa wisata }\end{array}$ \\
\hline 4 & Slukatan & $\begin{array}{l}\text { Belum sinergi antar kelompok dan antar dusun. Kelembagaan pengelola potensi desa seperti } \\
\text { BUMes dan Pokdarwis belum terbentuk. }\end{array}$ \\
\hline 5 & Balun & $\begin{array}{l}\text { Kurang minat pengolahan kopi, teknik budidaya, pengolahan, dan pasar masih rendah, usaha } \\
\text { masih dikelola personal, belum ada kelompok }\end{array}$ \\
\hline 6 & Ngargosari & $\begin{array}{l}\text { Kelembagaan BUMDes belum kuat, belum terorganisir dengan baik, dan belum tersentuh } \\
\text { inovasi }\end{array}$ \\
\hline 7 & Karangasem & $\begin{array}{l}\text { kurangnya pemahaman tentang desa wisata, masih mengandalkan objek, BUMDes belum } \\
\text { aktif, pokdarwis belum terbentuk }\end{array}$ \\
\hline 8 & Sindangbarang & $\begin{array}{l}\text { BUMDes masih belum optimal mengembangkan potensi desa, masih minimnya partisipasi } \\
\text { masyarakat karena tergantung dengan kepala desa, }\end{array}$ \\
\hline 9 & Wonoharjo & $\begin{array}{l}\text { Rendahnya pemahaman desa wisata dengan memanfaatkan potensi alam, budaya, seni dan } \\
\text { kuliner lokal, kelembagaan (Pokdarwis) belum optimal. }\end{array}$ \\
\hline 10 & Tumanggal & $\begin{array}{l}\text { Belum ada kreativitas yang memiliki nilai tambah, seperti pengolahan benang menjadi produk } \\
\text { lain. }\end{array}$ \\
\hline 11 & Tegalsari & BUMDes belum memiliki konsep usaha pengelolaan, masih minimnya pengetahuan \\
\hline 12 & Langkap & $\begin{array}{l}\text { Belum memiliki konsep pengembangan desa wisata, kapasitas SDM masih kurang, kelem- } \\
\text { bagaan (Pokdarwis) belum ada, BUMDes pasif }\end{array}$ \\
\hline 13 & Banjaran & $\begin{array}{l}\text { Belum adanya kelembagaan pengelola wisata yang kompeten untuk membangun kawasan } \\
\text { wisata }\end{array}$ \\
\hline 14 & Sikasur & $\begin{array}{l}\text { Kurangnya penguasaan konsep desa wisata (alam, seni budaya dan kuliner), kelembagaan } \\
\text { BUMDes dan Pokdarwis belum optimal }\end{array}$ \\
\hline 15 & Karangtengah & $\begin{array}{l}\text { Jiwa kewirausahaan rendah, mengharapkan bantuan, pemerintah desa kurang memiliki visi, } \\
\text { kelembagaan masih lemah }\end{array}$ \\
\hline 16 & Sidomulyo & Keterbataan lapangan kerja banyak meantau, semangat rendah, dukungan pemdes rendah \\
\hline 17 & Wlahar & $\begin{array}{l}\text { Belum ada penguasan teknik pengolahan sereh yang lebih baik, pangsa pasar masih terbatas } \\
\text { ke pihak tertentu, kelembagaan lemah }\end{array}$ \\
\hline 18 & Karangasem & $\begin{array}{l}\text { Pengelolaan pamsimas kurang optimal, kendal teknis terkait kualitas air, perlu peningkatan } \\
\text { aspek manajerial dan teknis pengelolaan air bersih }\end{array}$ \\
\hline 19 & Cingkrong & $\begin{array}{l}\text { Kapasitas SDM pengelola kurang, potensi objek wista lain (sawah, seni, olahan) belum dikem- } \\
\text { bangkan }\end{array}$ \\
\hline 20 & Krakal & $\begin{array}{l}\text { Beluma da variaso olahan tahu, jangkauan pasar terbatas, harga jual belum kompetitif. Kelom- } \\
\text { pok olahan belum ada }\end{array}$ \\
\hline 21 & Purworejo & $\begin{array}{l}\text { Kurang pengolahan, ikan tangkapan dijual mentah, harga rendah, kualitas masih rendah, ban- } \\
\text { yak ibu-ibu menganggur di rumah }\end{array}$ \\
\hline 22 & Karangmangu & $\begin{array}{l}\text { Kreativitas rendah, sulit menerima perubahan atau ide baru. Belum memiliki pemahaman } \\
\text { pasar yang baik, lemahnya kelembagaan }\end{array}$ \\
\hline
\end{tabular}

Sumber: Data primer (2019) 
mengolah terlebih dahulu. Banyak hasil panen atau tangkapan ikan dijual mentah, harga rendah, olahan yang ada masih tradisional kualitas masih rendah, cepat busuk, harga rendah.

Dari aspek kelembagaan, belum memiliki kesiapan, masih jarang ditemukan adanya lembagalembaga ekonomi desa yang kuat dan menjadi sarana usaha bersama, kelompok-kelompok usaha seperti pertanian, kerajinan, UMKM olahan relatif belum terbentuk dengan kuat. Masing-masing usaha dijalankan sendiri-sendiri. Di beberapa desa terdapat hambatan belum sinerginya antara pemerintah desa sebagai pengelola dengan kelembagaan pengguna di masyarakat, sebagian belum terdisitribusi secara jelas, sebagian masih terjadi perdebatan dan sebagian lagi masih belum ada distribusi, meskipun demikian, di sebagian desa masalah tersebut sudah terselesaikan.

BUMDes di desa-desa lokasi penelitian masih menghadapi masalah kekurangan SDM, permodalan dan jaringan usaha. Masih banyak BUMDes belum memiliki skema usaha yang jelas, masih lemahnya kapasitas kelembagaan dan SDM, permodalan masih menjadi hambatan. Hal ini sejalan dengan hasil penelitian Syaputra, dkk (2017) temtang model pengembangan BUMDes di Jambi, menyebutkan ada beberapa kondisi umum mengenai peran BUMDes, yaitu: pertama, sebagain besar BUMDes menghadapi masalah kualitas SDM, kedua, aktor penting adalah Kepala Desa, Badan Perwakilan Desa (BPD), dan Ketua/Direktur BUMDes.

Dari aspek sarana parsaran biasanya yang dikeluhkan adalah sarpars transportasi (jalan), sarpras produksi (peralatan dan teknologi), serta aksesibiltas lain seperti komunikasi (sinyal) yang terbatas. Dana desa sebagian sudah diarahkan, namun belum mampu menyelesaikan secara tuntas, masih mebutuhkan waktu bertahap. Sarpras tersebut dikeluhkan menjadi salah satu penghambat pengembagan usaha perdesaan.

\section{Faktor-Faktor Kunci Inovasi di Desa}

Di banyak desa tumbuh komitmen kepala desa, perangkat desa, dan pemuda serta masyarakat untuk memanfaatkan sumber daya alam dengan inovasi-inovasi baru. Komitmen kepala desa untuk mengalokasikan sumberdana desa dalam pemanfaatan SDA juga mulai muncul. Peran serta masyarakat juga memiliki pengaruh yang besar dalam pengembangan potensi desa.

Dari aspek sumber daya alam, pemanfaatan sebagai area/wahana wisata, pasar desa/pasar wisata, serta usaha BUMDes juga mulai muncul. Oleh sebab perlu didukung peningkatan pemahaman dan pergeseran mindset masyarakat agar menggunakan pola pikir baru, cara baru dan teknik baru dalam pengeloaan sumber daya. Dari aspek SDM ada beberapa peluang yang bisa diharapkan dari perdesaan di kawasan ini. Pertama adalah adanya potensi tenaga-tenaga muda yang sekarang mungkin enggan menggeluti sektor pertanian, namun memiliki beberapa ide untuk sektor lain seperti industri kreatif, UMKM, wisata, atau jasa. Oleh sebab itu bisa dibangun sinergi antar generasi, misalnya generasi tua memproduksi, generasi muda mengemas dan memasarkan dengan model yang interaktif sehingga harga produk lebih baik, generasi muda juga relatif memiliki jaringan yang luas. Beberapa desa juga memiliki tim kreatif dari para pemuda, terutama para sarjana yang kembali ke desa sebagai pelopor ide-ide inovasi. Untuk SDM secara umum memang diperlukan peningkatan kapasitas untuk mengembangkan potensi mereka, serta perlunya membangun jejaring yang lebih luas untuk mengoptimalkan potenmsi, serta menyusun konsep pengembangannya.

Dari aspek sosial, beberapa program telah mendorong meningkatnya peranserta dan partisipasi masyarakat dalam pembangunan. Dengan demikian ada peluang untuk mendorong masyarakat menjadi pelaku yang aktif mengelurkan ide-ide inovasi. Dari aspek sumber daya ekonomi, adanya komitmen pimpinan desa di hampir semua desa lokasi penelitian memiliki komitmen yang kuat untuk megembangkan desa melalui alokasi angaran dan sumber daya. Beberapa desa mendanai BUMDes dengan APBDes yang cukup besar untuk menggerakkan ekonomi desa. Pemerintah desa dengan dana desanya bisa didorong untuk menguatkan sektor unggulan melalui BUMDes atau lembaga lain. Peningkatan dukungan pemerintah desa dalam peningkatan kapasitas SDM, terutama kelompok pemuda untuk mengelola potensi lahan dan produk lokal juga diperlukan. Dari aspek kelembagan, berdasarkan pengamatan di lokasi penelitian, dalam kontsk sumber daya tersebut di atas, maka terdapat sumber daya potensial berupa kelembagaan ekonomi dan sosial. Lembaga desa yang memiliki potensi cukup besar adalah Badan Usaha Milik Desa (BUMDes).

Berdasarkan kondisi lapangan, hampir sebagian besar desa telah mengupayakan berdirinya BUMDes sebagai penggerak ekonomi desa. Status BUMDes di sebagian besar desa masih dalam tahap perintisan atau embrio, serta belum memiliki skema usaha yang jelas. Beberapa unit usaha yang akan digarap oleh sebagian besar BUMDes antara lain jasa persewaan kios, jasa pembayaran rekening listrik, PDAM, toko kelontong, jasa penyewaan peralatan, simpan pinjam, pariwisata, industri olahan.

BUMDes memiliki peran strategis karena dapat menjadi mitra usaha masyarakat, menerapkan perekonomian desa, serta dapat menjadi saluran insentif dari pemrintah dan pemerintah desa kepada sektor usaha masyarakat. Melalui BUMDes, pemerintah desa bisa mengalokasikan APBDes 
Tabel 6.

Faktor Pendorong Inovasi di Desa

\begin{tabular}{|c|c|c|c|}
\hline No & Desa & Pelaku/pendorong Inovasi & Fasilitasi yang diperlukan \\
\hline 1 & Gunungsari & Kelompok olahan kopi, kepala desa & insentif, pelatihan, jaringan \\
\hline 2 & Babadan & Kelompok tani, pemuda, kepala desa & kerjasama, infrastruktur \\
\hline 3 & Lamuk & $\begin{array}{l}\text { Kepala desa, Perangkat Desa, BUMDes, } \\
\text { pemuda }\end{array}$ & jaringan wisata, olahan kopi \\
\hline 4 & Slukatan & Sinergi antar kelompok, pemuda & $\begin{array}{l}\text { penguatan peran pemerintah desa, infrastruktur, } \\
\text { kerjasama }\end{array}$ \\
\hline 5 & Balun & $\begin{array}{l}\text { Pembudidaya kopi, kepala desa dan perang- } \\
\text { kat desa }\end{array}$ & jaringan pasar kopi, penguatan kelembagaan \\
\hline 6 & Ngargosari & Pengelola wisata, BUMDes, pemerintah desa & $\begin{array}{l}\text { Peningkatan Kapasitas SDM, insentif pariwisata, } \\
\text { kerjasama }\end{array}$ \\
\hline 7 & Karangasem & $\begin{array}{l}\text { Kepala Desa, perangkat desa, pendamping } \\
\text { desa }\end{array}$ & pelatihan dan peningkatan kapasitas SDM \\
\hline 8 & Sindangbarang & Kepala Desa, BUMDes, kelompok tani & $\begin{array}{l}\text { pemberdayaan masyarakat, peningkatan kapasitas } \\
\text { SDM }\end{array}$ \\
\hline 9 & Wonoharjo & $\begin{array}{l}\text { LSM, Kepala desa, Pokdarwis, BUMDes, } \\
\text { pemuda }\end{array}$ & sinergi program, kolaborasi antar kelompok \\
\hline 10 & Tumanggal & $\begin{array}{l}\text { Kepala desa, pemuda, pengrajin, Pokdarwis } \\
\text { dan BUMDes }\end{array}$ & jaringan pasar, peningkatan kapasitas SDM \\
\hline 11 & Tegalsari & $\begin{array}{l}\text { BUMDes, perangkat desa, kelompok mas- } \\
\text { yarakat, tokoh masyarakat }\end{array}$ & jaringan pasar, teknologi, insentif \\
\hline 12 & Langkap & Kepala desa, pemuda, BUMDes & peningkatan kapasitas SDM \\
\hline 13 & Banjaran & Pemuda, LMDH, Pokdarwis, & kemiteraan, kapasitas SDM \\
\hline 14 & Sikasur & Kepala Desa, Pokdarwis/pemuda & peningkatan kapasitas SDM \\
\hline 15 & Karangtengah & Pemuda, pengrajin, pemerintah desa, & $\begin{array}{l}\text { Peningkatan kapasitas SDM, pendampingan, } \\
\text { jaringan }\end{array}$ \\
\hline 16 & Sidomulyo & $\begin{array}{l}\text { Pemuda, pengrajin, pendamping desa, pe- } \\
\text { merintah desa, }\end{array}$ & insentif, pendampingan, kapasitas SDM, jaringan \\
\hline 17 & Wlahar & $\begin{array}{l}\text { Pemuda, pelaku usaha, petani sereh, pemer- } \\
\text { intah desa, }\end{array}$ & peningkatan penguasaan teknologi, jaringan pasar \\
\hline 18 & Karangasem & $\begin{array}{l}\text { Kepala desa, BUMDes/Pamsimas, perangkat } \\
\text { desa }\end{array}$ & peningkatan penguasaan teknologi, kapasitas SDM \\
\hline 19 & Cingkrong & $\begin{array}{l}\text { Kepala desa, BUMDes, pemuda, kelompok } \\
\text { tani }\end{array}$ & $\begin{array}{l}\text { peningkatan kapasitas SDM, pomosi, jairngan } \\
\text { kerjasama }\end{array}$ \\
\hline 20 & Krakal & $\begin{array}{l}\text { Pelaku UMKM (tahu, genitri), pemerintah } \\
\text { desa }\end{array}$ & $\begin{array}{l}\text { pendampingan, kapasitas SDM, insentif, jaringan } \\
\text { pasar }\end{array}$ \\
\hline 21 & Purworejo & Kepala desa, pelaku industri olahan ikan & $\begin{array}{l}\text { insentif, pelatihan, jaringan pasar, pembenahan } \\
\text { infrastruktur }\end{array}$ \\
\hline 22 & Karangmangu & $\begin{array}{l}\text { Kepala desa, pelaku usaha olahan ikan, } \\
\text { pemuda }\end{array}$ & $\begin{array}{l}\text { jaringan pasar, kolaborasi antar unsur, kerjasama, } \\
\text { kapasitas SDM }\end{array}$ \\
\hline
\end{tabular}

misalnya dari dana desa, selain itu masyarakat juga bisa berpartisipasi menanamkan modal nya. Keberadaan BUMDes bisa memberikan kesempatan berusaha, lapangan kerja, dan mitra usaha masyarakat. Hal ini sesuai hasil penelitian Ramli dkk (2018) mengidentifikasi bahwa peran BUMDesa strategis dalam meningkatkan kesejahteraan masyarakat desa melalui perbaikan pelayanan umum, pertumbuhan dan pemerataan ekonomi desa dari pemerintah desa kepada masyarakat.

BUMDes merupakan instrumen untuk mengembangkan perekonomian lokal secara kolektif berbasis potensi dan kekuatan desa. Di sisi lain dana desa juga sangat membantu pemerintah desa dalam membangun infrastruktur serta kesejahteraan masyarakat. Penelitian Nasution 
(2018) tentang model BUMDes Inovatif di Desa Panggungharjo (BUMDes Panggung Lestari) menempatkan "BUMDes tidak hanya sebagai lembaga sosial (social intitutions) dan lembaga komersial (comercial institutions), akan tetapi juga sebagai sebagai lembaga manjemen sumber daya milik bersama dalam menangani konflik yang melibatkan berbagai stakeholder desa. BUMDesa menjadi wadah yang mengatur keterlibatan stakeholder untuk mendukung kegiatan secara kolektif warganya. Berdasarkan kondisi lapangan, maka perlu memperkuat potensi BUMDes sebagai lembaga pengerak ekonomi desa, mulai dari proses produksi sampai pemasaran baik untuk produk pertanian, peternakan, UMKM, maupun perkebunan.

Selain BUMDes, kelembagaan lain seperti kelompok tani, kelompok wanita tani, PKK, kelompok usaha/ UMKM serta kelompok pemuda juga menjadi lembaga penting penggerak ekonomi desa. Begitu juga dalam pengelolaan potensi wisata saat ini telah muncul banyak kelompok sadar wisata (Pokdarwis) yang terutama dikelola oleh para pemuda. Dalam konteks kawasan dan aksesibilitas, dana desa dan swadaya masyarakat bisa menjadi solusi. Konsep pengembangan perdesaan juga sebaiknya dilakukan di tingkat kecamatan karena memiliki keterkaitan potensi antar desa, dan akan lebih baik dikelola dalam satu kawasan.

Berdasarkan penjelasan mengenai potensi tersebut di atas, serta kondisi lapangan ditemukan bahwa faktor-faktor kunci keberhasilan inovasi di perdesaan adalah sinergi antara optimalisasi potensi sumber daya alam, oleh manusia, melalui sistem sosial dan ekonomi yang digerakkan oleh pelaku utama desa, yaitu kepala desa dan perangkatnya, tokoh masyarakat, dan pelopor, terutama dari kalangan muda.

Kemajuan inovasi yang berdampak pada kesejahteraan tidak hanya mengandalkan penguasaan sumber daya alam, serta tidak juga sepenuhnya terletakpada kapasitas SDM.Dinamisasi potensi SDM dalam mengelola SDA perlu digerakkan oleh sumber daya sosial yang dinamis. Adanya person atau kelompok masyarakat yang dinamis dan memiliki banyak gagasan menjadi potensi yang sangat penting. Tokoh-tokoh inovasi yang dimaksud adalah para pelopor, baik kalangan petani, pemuda, pelaku UMKM yang memiliki semangat kreatifitas dan inovasi, berani mengambil risiko dan memiliki gagasan berbeda merupakan faktor kunci yang dibutuhkan sebagai agen inovasi. Di sisi lain peran pemerintah desa di hampir semua lokasi penelitian merupakan faktor kunci pendorong dan fasilitator bagi masyarakat. Sinergi pemerintah desa dan masyarakat merupakan faktor penting mendorong inovasi tersebut.

Hal ini sesuai dengan hasil penelitian Kartika, dkk (2019) tentang Pemberdayaan Masyarakat di
Desa Cibuntu, Kuningan menemukan bahwa faktor kunci keberhasilan adalah inisiasi masyarakat yang kuat, namun demikian masih tetap memerlukan dorongan dari pemerintah, serta bantuan pihak luar seperti akademisi dan maupun praktisi. Penelitian Jati, dkk (2013) tentang model pengembangan Desa Inovatif di Desa Kalisari, Kabupaten Banyumas menyimpulkan bahwa model pengembangan desa inovatif mensyaratkan pentingnya komunikasi dan pentingnya peran penyelenggara pemerintahan di tingkat desa (Kades dan Badan Permusyawaratan Desa), serta elemen masyarakat lain khususnya pemuda dan kelompok UKM dimana mereka mendominasi kegiatan perekonomian di desa.

Masyarakat adalah pelaku utama, pemerintah desa sebagai fasilitator dan kolaborator. Dengan demikian tugas pemerintah desa adalah memberdayakan masyarakat dengan sumber daya mereka seperti pengetahuan, skill/keterampilan dan daya kreasi. Sebagaimana hasil penelitian Hidayah (2018) tentang pemberdayaan masyarakat melalui inovasi olahan kedelai, ialah pentingnya pemanfaatan skill masyarakat dan aset yang perlu menggunakan langkah-langkah melalui 5D yaitu Discover, Dream, Desgin, Define, Destiny. Begitu juga dengan hasil penelitian Safitri (2018) menekankan pentingnya membangun kesadaran masyarakat tentang potensinya. Langkah-langkah ini memerlukan peran pelopor mendorong masyarakat sehingga mampu dimanfaatkan, perlunya memberikan pengetahuan, wawasan, keterampilan life skills, dorongan, dan motivasi.

Selain itu, dibutuhkan penguatan peran pihakpihak terkait, di antaranya akademisi melakukan fasilitasi dan riset sekaligus memberikan solusi, pihak bisnis melakukan kolaborasi, pelatihan keterampilan dan jejaring usaha. Pemerintah melakukan fasilitasi peralatan dan modal untuk mengatasi keterbatasan peralatan, permodalan, promosi, pemasaran dan regulasi (Suwandana et al., 2016).

Peran pendamping desa juga sangat penting di dalam mendukung kinerja pemerintah desa. Hal ini diperlukan karena di sebagian besar desa, aparat pemerintah desa didominasi oleh personel dengan umur paruh baya dan pendidikan yang minim (Sofi, 2020). Peran pendamping desa adalah meningkatkan kapasitas kinerja pemerintah desa, sekaligus membantu membangun kemiteraan dengan berbagai pihak.

Aksesibilitas merupakan persyaratan yang sangat penting bagi dinamika sebuah desa. Aksesibilitas fisik sepetti jaringan jalan, aksesiblitas informsi dan pengetahuan seperti jaringan internet, telepon, dan program pelatihan sangat mendukung dinamika inovasi di desa. Penelitian Amongjati, dkk (2019) tentang peran pesantren dalam perubahan sosial menemukan bahwa salah satu sumber 
perubahan sosial adalah pembukaan isolasi wilayah, adanya agen perubahan sosial yang mempercepat (akseletator) perubahan dengan berperan sebagai social entrepreneur, serta adanya inovasi sosial berupa kolaborasi, bimbingan, akses informasi dan menjembatani program pemerintah, swasta, dan BUMN.

Dengan demikian, strategi mendorong inovasi di perdesaan dimulai dengan menjadikan masyarakat sebagai pelaku utama inovasi. Melalui pengetahuan, keterampilan, pengalaman, kebiasaan, dan pola hidup sehari-hari masyarakat telah memiliki potensi yang cukup banyak. Hal yang perlu diubah adalah cara pandang terhadap potensi mereka. Seringkali masyarakat memiliki potensi namun tidak menyadarinya, hal ini disebabkan oleh pola pikir yang masih lama. Hasil penelitian Kusumastuti, dkk (2019) tentang model desa Wisata Bisnis Tegalwaru mengidentifikasi keunggulan pemberdayaan masyarakat berbasis indigenous values mengandalkan sumber daya alam dan human capital, serta adanya kolaborasi antar stakeholder kunci.

Tidak hanya cukup itu, berdasarkan pengamatan terhadap kondisi lapangan di desadesa, peran pemerintah desa cukup besar dalam mendinamisasi inovasi. Oleh sebab itu, strategi harus dimulai dari penguatan pemerintah desa sebagai fasilitator dan kolaborator inovasi. Peran pemerintah desa memberikan fasilitas ini akan meningkatkan produktifitas masyarakat. Sebagai contoh desa Cinkgrong dengan peran kepala desa membuat BUMDes dan wahana wisata, pemerintah Desa Sikasur, Desa Lamuk, Desa Sindangbarang, Desa Karangasem Klaten, dan beberapa desa lain menunjukkan besarnya peran kepala desa.

Hal ini sesuai dengan hasil penelitian Rengganis \& Atmojo (2019) tentang inovasi Desa Mart di Desa Dlingo Melalui BumDes dimana peran pemerintah desa cukup besar dalam meningkatkan potensi masyarakat melalui pelatihan serta motivasi bagi masyarakat. Dengan kegiatan tersebut mereka mampu mengembangkan potensi menjadi produk untuk dijual di dalam Desa Mart. Begitu juga dengan penelitian Andini (2015) studi tentang potensi ekonomi masyarakat di Desa Muktiharjo, Margorejo, Pati menunjukkan bahwa pemberdayaan potensi ekonomi desa seperti pertanian/perkebunan, perikanan, pariwisata dan UKM perlu mendapatkan dukungan pemerintah kabupaten, kecamatan, dan desa yang menjadikan masyarakat sebagai subjek dan objek pembangunan.

Hal lain yang tidak bisa dipisahkan adalah perlnya membangun kemiteraan antar pelaku di desa dengan pihak di luar desa, yang difasilitasi pemerintah desa dan lembaga-lembaga masyarakat desa. Hal ini penting untuk membuka akses dan wawasan masyarakat desa terhadap ide-ide inovasi, serta saluran pasar dan dukungan sumber daya inovasi. Kemiteraan terjadi baik di internal desa, maupun dengan pihak luar sebagai salah satu pendorong keberhasilan inovasi. Sesuai dengan hasil penelitian Rengganis \& Atmojo (2019) Desa Mart bisa mejadi mitra usaha masyarakat, dimana toko kelontong milik masyarakat mengambil barang di Desa Mart, pemerintah desa juga menjalin kemitraan dengan Bulog dan BNI.

Konsep sinergi antara pemerintah daerah, pemerintah dan masyarakat desa, pelaku usaha, dan akademisi menjadi kunci untuk mengatasi kendala tersebut. Selain itu kerjasama dengan pakar terkait baik dari kalangan akademisi maupun praktisi juga dilakukan dengan optimal. Sebagai contoh dalam pengembangan konsep inovasi, transfer teknologi, pengembangan inovasi dan pelatihan/ aplikasi selalu melibatkan pakar dan praktisi yang kompeten.

\section{KESIMPULAN}

Desa memiliki berbagai sumber daya alam, manusia, sosial, maupun ekonomi yang bisa dikelola dengan inovasi. Secara umum sumber daya alam masih dianggap faktor utama perekonomian, namun demikian telah mulai muncul kesadaran baru untuk mengelola sumber daya tersebut dengan cara baru dengan tumbuhnya kegiatan wisata, industri kreatif, dan pengolahan produk pascapanen.

Beberapa kendala terkait inovasi di desa adalahh manajerial sumber daya alam, SDM, sosial, sumber daya ekonomi, kelembagaan, dan sarana prasarana. Dari aspek manajerial sumbedaya alam masih kesulitan menemukan ide untuk mengolahnya dengan inovasi. Dari aspek SDM masih terbatas ide-ide, minimnya kepeloporan dan jiwa kewirausahaannya, serta penguasaan pengetahuan dan teknologi. Dari aspek sosial, menghadapi masalah partisipasi masyarakat tergantung figur, sulit mencoba hal-hal baru, dan masih lemahnya peran lembaga-lembaga desa. Dari aspek ekonomi terkendala mentalitas ingin cepat menghasilkan uang, tanpa mengolah terlebih dahulu, serta rendahnya kekuatan lembaga-lembaga ekonomi, kurangnya sinergi antarpelaku ekonomi.

Faktor-faktor kunci yang mendorong berkembangnya inovasi perdesaan tidak hanya mengandalkan penguasaan sumber daya alam, namun dinamisasi potensi SDM yang digerakkan oleh sumber daya sosial yang dinamis. Diperlukan adanya tokoh-tokoh inovasi sebagai pelopor yang berani mengambil risiko dan memiliki gagasan berbeda serta didukung pemerintah desa dengan melibatkan stakeholder terkait.

Penelitian ini memiliki keterbatasan dari aspek waktu, tenaga, dan metode. Masih banyak aspek yang masih perlu dikaji, misalnya mengenai pola hubungan sosial-ekonomi, konflik kepentingan, 
persaingan dan jaringan kerjasama yang sangat mempengaruhi dinamika inovasi produk-produk unggulan desa. Tema-tema tersebut sangat penting untuk dikaji sebagai pelengkap dari kajian ini.

Berdasarkan kesimpulan di atas, maka dapat disulkan beberapa saran yaitu: 1) Pendampingan intensif kepada desa untuk menggali gagasan untuk meningkatkan pemahaman dan mengggali potensi secara optimal; 2) Mendorong optimalisasi sumber daya desa seperti anggaran atau dana desa dalam mendorong inovasi desa, serta penguatan kelembagaan sosial dan ekonomi di desa; 3) Memeprkuat jejaring inovasi desa sebagai bahan sharing pengetahuan, sumber daya dan sarpras, serta teknologi yang bisa dimulai di tingkat kecamatan - kabupaten, menggandeng beberapa institusi lainnya;

\section{Daftar Pustaka}

Amongjati, S. A., Kolopaking, L. M., \& Saharuddin, S. (2019). Pesantren's Social Innovation in Driving Agriculture and Social Change in Village. Sodality: Jurnal Sosiologi Pedesaan, 7(2), 159-166. https://doi.org/10.22500/ sodality.v7i2.26221

Andini, U. H. (2015). Pemberdayaan Ekonomi Masyarakat Dari Desa Tertinggal Menuju Desa Tidak Tertinggal (Studi di Desa Muktiharjo Kecamatan Margorejo Kabupaten Pati). Jurnal Administrasi Publik, 3(1), 7-11. http:// administrasipublik.studentjournal.ub.ac.id/ index.php/jap/article/view/737

BPS Jawa Tengah. (2020a). Provinsi Jawa Tengah Dalam Angka 2019. Jateng.Bps.Go.Id. https:// jateng.bps.go.id/publication/2019/08/16/ fcb9efa7796cdbc491325688/provinsi-jawatengah-dalam-angka-2019.html

BPS Jawa Tengah. (2020b). Provinsi Jawa Tengah Dalam Angka 2020. Jateng.Bps.Go.Id. https:// jateng.bps.go.id/publication/2020/04/27/ b96a0d5f63de624aa600934d/provinsi-jawatengah-dalam-angka-2020.html

Daldjoeni, N., \& Suyitno, A. (2004). Pedesaan, lingkungan dan pembangunan. Alumni.

Eko, S. (2004). Reformasi Politik dan Pemberdayaan Masyarakat. APMD Press.

Hidayah, A. A. (2018). Pemberdayaan Masyarakat melalui Inovasi Pengelolaan Kedelai menjadi Cookies Tempe untuk Meningkatkan Perekonomian di Desa Wonoasri Kecamatan Wonoasri Kabupaten Madiun [UIN Sunan Ampel Surabaya]. http://digilib.uinsby.ac.id/24494/

Jamaludin, A. N. (2017). Sosiologi Perdesaan. Pustaka Setia.

jatengprov.go.id. (2020). Sistem Informasi Desa Jawa Tengah. Sidesa.Jatengprov.Go.Id. https:// sidesa.jatengprov.go.id/
Jati, D. P., Suroso, A., \& Suwandari, L. (2013). Model Pengembangan Desa Inovatif Desa Kalisari Kabupaten Banyumas. http://jp.feb. unsoed.ac.id/index.php/sca-1/article/ viewFile/253/258

Kartika, T., Afriza, L., \& Fajri, K. (2019). Pemberdayaan Masyarakat di Desa Wisata Cibuntu Kabupaten Kuningan Provinsi Jawa Barat. Journal of Indonesian Tourism, Hospitality and Recreation, 2(1), 11-24. https://doi.org/10.17509/jithor. v2i1.16427

Kusnadi, E., \& Iskandar, D. (2017, November 30). Peranan Tokoh Masyarakat dalam Membangun Partisipasi Kewargaan Pemuda Karang Taruna. Konferensi Nasional Kewarganegaraan III. http://eprints.uad.ac.id/9926/

Kusumastuti, R., Sakapurnama, E., Fauzi, A., \& Nurita, P. (2019). Memahami Model Bisnis Praktek Inovasi Sosial : Kajian Desa Wisata Bisnis Tegal Waru. AdBispreneur, 3(2), 131-142. https:// doi.org/10.24198/adbispreneur.v3i2.18667

Nasution, F. G. A. (2018). Pengujian Terhadap Assesment Model BUM Desa Inovatif(Studi Kasus BUM Desa Panggung Lestari, Desa Panggungharjo, Kabupaten Bantul). http:// repo.apmd.ac.id/id/eprint/803

Nurgiarta, D. A., \& Rosdiana, W. (2019). Pemberdayaan Masyarakat Melalui Program Inovasi Desa (PID) di Desa Labuhan Kecamatan Brondong Kabupaten Lamongan. Publika, 7(3), 1-8. https://jurnalmahasiswa.unesa.ac.id/ index.php/publika/article/view/27137

Prasodjo, T. (2017). Tata Kelola Administrasi dan Pengembangan Desa Inovatif Berbasis Riset. Jurnal Ad'ministrare, 4(1), 35-40. https://doi. org/10.26858/ja.v4i1.3444

Purnomo, A. M., Satria, A., \& Rustiadi, E. (2011). Menuju Desa 2030. Crescent Press.

Ramli, A. R., Wahyuddin, Mursyida, J., \& Mawardati. (2018). Ekonomi Desa: Analisa Pemberdayaan ekonomi Masyarakat Desa. Natural Aceh. https://www.researchgate. net/publication/328403097_Ekonomi_Desa_ Analisa_Pemberdayaan_ekonomi_Masyarakat_ Desa

Rengganis, I. P., \& Atmojo, M. E. (2019). Inovasi Pemerintah Desa Dlingo dalam Mewujudkan Pemberdayaan Masyarakat Melalui Desa Mart pada Tahun 2017. Jurnal Agregasi : Aksi Reformasi Government Dalam Demokrasi, 7(1), 79-90. https://doi.org/10.34010/agregasi. v7i1.1435

Rustiadi, E., Saefulhakim, S., \& Panuju, D. R. (2011). Perencanaan dan Pengembangan Wilayah. Yayasan Obor Indonesia.

Safitri, E. (2018). Optimalisasi Pemanfaatan Potensi Lokal dalam Pemberdayaan Ekonomi Masyarakat di Desa Sukamulya Kecamatan 
Banyumas Kabupaten Pringsewu [UIN Raden Intan Lampung]. http://repository.radenintan. ac.id/5251/

Setya Yunas, N. (2019). Implementasi Konsep Penta Helix dalam Pengembangan Potensi Desa melalui Model Lumbung Ekonomi Desa di Provinsi Jawa Timur. Matra Pembaruan, 3(1), 37-46. https://doi.org/10.21787/ mp.3.1.2019.37-46

Sofi, I. (2020). Implementasi Padat Karya Tunai Dana Desa untuk Masyarakat Miskin di Kabupaten Pasuruan dan Kabupaten Probolinggo. Matra Pembaruan, 4(1), 25-35. https://doi. org/10.21787/mp.4.1.2020.25-35

Soleh, A. (2017). Strategi Pengembangan Potensi Desa. Jurnal Sungkai, 5(1), 32-52. https://doi. org/10.30606/JS.V5I1.1181

Sugiyono. (2008). Metode Penelitian Pendidikan: Pendekatan Kuantitatif, Kualitatif dan R\&D. Alfabeta.

Sunarjaya, G., Antara, M., \& Prasiasa, D. P. O. (2018). Kendala Pengembangan Desa Wisata Munggu, Kecamatan Mengwi, Badung. Jurnal Master Pariwisata, 4(2), 215-227. https://doi. org/10.24843/JUMPA.2018.v04.i02.p04
Suwandana, E., Mutaqin, A. Z., Rostiawati, E., \& Oktaviana, O. (2016). Kajian Penguatan Lembaga Kolaboratif dalam Penguatan Desa ... Kajian Penguatan Lembaga Kolaboratif. Proceeding Pertemuan Ilmiah Tahunan (PIT) Nasional Ke-2, 453-467. https://fdokumen. com/document/kajian-penguatan-lembagakolaboratif-dalam-penguatan-desa-kajianpenguatan.html

Syaputra, M. R., Daulay, A. R., \& Elwamendri. (2017). Model Pengembangan Bumdes Guna Meningkatkan Inovasi dan Kemandirian Masyarakat di Provinsi Jambi. https:// asnelly69.files.wordpress.com/2018/06/ laporan-penelitian-bumdes-final1.pdf

Usman, H., \& Akbar, P. S. (2008). Metodologi Penelitian Sosial (Edisi ke-2.). Bumi Aksara.

Winarno, B. (2008). Gagalnya Organisasi Desa dalam Pembangunan di Indonesia. Tiara Wacana.

Zuhal. (2010). Knowledge and Innovation Platform Kekuatan Daya Saing. PT Gramedia Pustaka Utama. 